\title{
EDUCAÇÃO POPULAR, SABERES TRADICIONAIS E DEBATES INSUBMISSOS: UM DIÁLOGO COM CARLOS RODRIGUES BRANDÃO
}

\author{
POPULAR EDUCATION, TRADITIONAL KNOWLEDGE AND \\ UNSUBMITTED DEBATES: A DIALOGUE WITH \\ CARLOS RODRIGUES BRANDÃO
}

\author{
Valéria Oliveira de Vasconcelos ${ }^{1}$ \\ Renata Evangelista Oliveira ${ }^{2}$
}

\begin{abstract}
RESUMO
Este artigo foi organizado a partir de um diálogo com Carlos Rodrigues Brandão, sobre a relação entre a Educação Popular com os saberes tradicionais e populares, com o campo e o rural, e sobre os múltiplos desafios dos dias atuais - agigantados pela atual Pandemia de Covid 19. Alinhavando passagens de sua trajetória com recortes de seus escritos, trazemos questões relacionadas às pautas insubmissas da Educação Popular e de suas bases, não hegemônicas, dialógicas e democráticas. Brandão apresenta o que para ele significa ser um educador insubmisso, e sobre a práxis insubmissa como um caminho para a Educação Popular, que fortalece a criticidade e gera insurgência contra todo e qualquer tipo de opressão. Falamos de sua militância ao longo da vida, das lutas contra injustiças e em busca de um mundo mais solidário. Trazemos à pauta ainda os saberes tradicionais e populares, o campo e o rural na Educação Popular, como aportes de insubmissão e resistência. Finalmente, discutimos como o ensinar-e-aprender pode dialogar com a Educação Popular e com os saberes tradicionais. Nas derradeiras palavras trazemos breves apontamentos sobre a coerência que ilustra a coerência o trilhar desse antropólogo entre seus dizeres e fazeres, ressaltando que, mesmo em meio a momentos tão difíceis: "o riso é uma arma de resistência", como dizia o ator Paulo Gustavo.
\end{abstract}

Palavras-chave: Educação Popular; Práxis insubmissa; Resistência.

\footnotetext{
${ }^{1}$ Atualmente é Professora do Programa de Mestrado em Educação do Centro Universitário Salesiano de São Paulo (UNISAL)/Americana. Vice-coordenadora do GT 06 - Educação Popular/Anped, 2019-2021. Doutora em Educação pela Universidade Federal de São Carlos/Universidade de Salamanca-Espanha. Pós-doutorado pelo Departamento de Pos-graduação em Educação Escolar da Universidade Júlio de Mesquita Filho (UNESP/Araraquara) e Pós-doutorado pelo Departamento de Ciências Ambientais da Universidade Federal de São Carlos. e-mail: valvasc2013@gmail.com

${ }^{2}$ Atualmente é Professora Associada do Departamento de Desenvolvimento Rural na Universidade Federal de São Carlos (UFSCar). Doutora em Ciência Florestal pela Universidade Estadual Paulista Júlio de Mesquita Filho(UNESP). e-mail: reolivei@ufscar.br
} 


\begin{abstract}
This article was organized from a dialogue with Carlos Rodrigues Brandão, about the relationship between Popular Education with traditional and popular knowledge, with the countryside and the rural, and about the multiple challenges of the present days - magnified by the current Pandemic of Covid 19. By weaving highlights of his trajectory and excerpts from his writings, we raise questions related to the unsubmissive agendas of Popular Education and its non-hegemonic, dialogical and democratic bases. Brandão presents what it means to him to be an unsubmissive educator and about unsubmissive praxis as a path to Popular Education, which strengthens criticism and generates insurgency against any and all types of oppression. We talk about his militancy throughout his life, his struggles against injustices, and the search for a more solidary world. We also bring to the discussion traditional and popular knowledge, the countryside and the rural in Popular Education, as contributions of insubordination and resistance. Finally, we discuss how teaching and learning can dialogue with Popular Education and traditional knowledge. In conclusion, we bring brief notes on the coherence that illustrates this anthropologist's pathways between his words and actions, emphasizing that "laughter is a weapon of resistance" even amid such difficult moments, as the actor Paulo Gustavo said.
\end{abstract}

Keywords: Popular Education. Unsubmissive praxis. Resistance.

\title{
PRIMEIRAS PALAVRAS
}

Algumas palavras querem dizer uma coisa só, ou pelo menos sonham com isso. Outras, ao contrário, podem significar muitas coisas. Podem traduzir seres ou ideias ora próximas, ora distantes. Podem significar algo e seu contrário. Podem estender o seu significado a tantos cenários que correm o risco de dizer tudo e coisa nenhuma... (BRANDÃO, 2015, p. 21)

A construção deste texto iniciou-se com a realização do que se pretendia uma entrevista com Carlos Rodrigues Brandão, com pauta e questões pré-definidas, e acabou se tornando um diálogo de algumas horas, extrapolando (claro, alimentada por toda a insubmissão de nosso interlocutor, e aquela necessária ao tema a que nos propomos) o que havíamos previsto e almejado.

Apresentamos aqui, portanto, os resultados do que escolhemos chamar de "diálogo", com uma compilação de nossa conversa com recortes e adequações aos limites deste ensaio. Em "triálogo" com esse renomado antropólogo e dos maiores representantes da Educação Popular no país e no mundo, com sua anuência e revisão, reelaboramos algumas questões originais, garimpamos trechos de sua fala, resgatamos vários de seus escritos em temáticas relacionadas, e incluímos novos aportes, para criar um texto (ao final - e por que não? construído a seis mãos). Nele, de forma insubmissa (e ousemos, prazerosa), abordamos - e discutimos - a relação entre a Educação Popular, os saberes tradicionais e populares, a relação 
com o campo e o rural, e os caminhos trilhados, considerando a atual conjuntura política, econômica e social em que se encontra nosso país, e o delicado momento causado pela Pandemia de Covid 19. São tempos de desafios - e sim, de esperança! Urge (re)construir formas de educação capazes de iluminar caminhos para essa nova era que se avizinha.

Nesse sentido, Brandão nos brinda com narrativas sobre sua trajetória, e suas memórias e escritos desde sempre apontam os primórdios da Educação Popular e da Cultura Popular como horizontes a serem retomados, vislumbrados e perseguidos. De início, sobre as origens do trabalho pedagógico emancipador, trazemos uma frase de Brandão que parece ser um bom lema para o enfrentamento da atual conjuntura: "Militávamos cantando. Educávamos poetando".

\section{O QUE SIGNIFICA SER UM/A EDUCADOR/A INSUBMISSO/A?}

Somos seres da natureza vivida como alguma experiência de cultura. Ora, se isto é assim, então a função do educador ganha a dimensão de um verdadeiro agente do processo mais importante de toda a vida: aprender a saber através do criar saberes para aprender (BRANDÃO; BORGES, 2008, p. 13).

Em muitas de suas falas pregressas, Brandão anuncia que uma educação dialógica pressupõe a construção de um saber ao mesmo tempo solitário, mas também solidário. Solitário porque há um saber que se constrói solitária e individualmente, mas há, simultaneamente, aquele saber construído coletivamente, partilhado por aqueles e aquelas que, juntos/as, aprendem. Essa educação talvez possa ser chamada de insubmissa, já que não se subordina a um pacote de conhecimentos a serem transmitidos/absorvidos, a uma relação supostamente hierárquica entre educador/a e educando/a (professor/a e aluno/a), aos papéis pré-definidos de "professor/a que ensina, aluno/a que aprende", e a uma descrição e expectativa meritocrática do "resultado final" do processo de aprendizagem.

Lembrando Brandão e Borges (2008):

O trabalho de aprender-a-saber é sempre uma múltipla experiência dialógica. "Múltipla" porque é algo vivido diariamente, a todo o momento, em situações, dentro de dimensões e através de relações cujo princípio fundador é a troca de sentidos dados a emoções e de significados em busca do conhecimento [...]. "Experiência" porque envolve sempre o próprio trabalho da vida e porque abarca a conexão entre conviver, criar, fazer algo para, com, ou através do conhecimento [...]. "Dialógica" porque é 
sempre o processo e o produto de uma troca. De uma reciprocidade (BRANDÃO; BORGES, 2008, p. 14).

Iniciamos o diálogo perguntando sobre sua dinâmica nesse contexto imposto pela Pandemia de Covid $19^{3}$ :

Brandão: Eu estou vivendo com muito pesar, tristeza e preocupação essa pandemia. Mas por outro lado, está sendo interessante, uma porque mesmo que virtualmente, eu estou em contato com um monte de gente - com a tristeza de não ser presencial, mas com a alegria de eu estar revendo pessoas que eu não via há trinta anos. E estou aproveitando para escrever como nunca, já que eu não estou viajando. O Rubem ${ }^{4}$ dizia: “o Brandão é o único cara que eu conheço que fica contente quando o autofalante do aeroporto avisa que o avião vai atrasar três horas, porque aí ele escreve um artigo". E aliás, é verdade. E eu estou escrevendo como nunca na vida. Estou podendo escrever o que eu quero... Passei um ano lendo muitos livros sobre escaladas de montanha, e eu hoje estou festejando o final de um livro meu chamado "O Primata que Aprende", que é um estudo de paleontologia da educação. Eu fiquei até triste de acabar, mas ele já está quase na página trezentos, estava na hora de acabar... Nesse ponto eu estou quase que querendo perenizar alguns momentos que estou vivendo durante a pandemia.

Valéria/Renata: Ler e escrever, fazer o que quer, já é insubmissão. Você se considera um educador insubmisso?

Brandão: Eu fui em tudo insubmisso, nesse meu relato de memória "Eu, Professor"5, para vocês terem uma ideia, a escola vai entrar quase no meio do livro e vai entrar com má vontade. E eu começo dizendo que não conheço ninguém que tenha vivido experiências de estudante como eu... Estudei em sete colégios porque eu era muito mau aluno - eu fui expulso do colégio São Bento com oito anos e depois meu ingresso foi recusado em um outro colégio religioso, o

\footnotetext{
${ }^{3}$ Trechos transcritos das falas durante o diálogo estão aqui marcados em itálico. As perguntas previamente definidas na pauta seguem transcritas, sem marcação.

${ }^{4}$ Brandão se refere ao escritor e amigo Rubem Alves.

${ }^{5}$ Livro inédito a ser publicado no ano de 2021 em parceria com o Grupo de Estudos e Pesquisas em Educação de Jovens e Adultos (GEPEJA/UNICAMP).
} 
Padre Vieira. Eu estudei em colégio particular-católico, particular-leigo e público, estudei em escola confessional, pública e militar... [...] eu fui um péssimo aluno, quando meu querido amigo e professor Régis de Moraes escreveu um livro chamado Sala de aula, que espaço é esse ${ }^{6}$ ele me pediu um artigo e eu disse que escreveria só se pudesse contar a minha vida de vagabundo. Ele aceitou e eu escrevi um artigo chamado "A turma de trás". Quando eu escrevi esse artigo fui entrevistado pelo Estadão que publicou uma matéria, e depois fizeram um quadro no Fantástico em que eles saíram procurando e encontraram pessoas que se destacaram nas artes e na ciência e que foram vagabundos também. E me contaram que foi uma enorme dificuldade porque eles sabiam de vários, mas quase ninguém teve a minha honestidade...

Valéria: Tem uma frase, acho que do Rubem Alves, que diz: “Às vezes a recusa do aprender é a melhor forma de expressar inteligência...".

Brandão: Eu assino embaixo. Tanto que nas minhas memorias do "Eu, professor", logo o segundo capítulo - "Brincar de aprender" - eu faço uma antropologia de todas as brincadeiras desde a minha infância até a juventude, que nos ensinavam muito mais que os preceitos nas escolas, inclusive os caretíssimos preceitos nas escolas religiosas. Porque eu fui de duas escolas católicas, três escolas leigas e uma militar. Eu vou até contar uma história, uma vez eu fui para a Colômbia - na cidade de Pasto - e eu tinha levado uma biografia do Gabriel Garcia Márquez, que é a biografia dele de jovem ${ }^{7}$, e ele conta uma história muito interessante, que durante um tempo ele foi amante de uma mulher cujo marido era comandante de um barco que navegava sobre o rio Madalena. Então, esse homem três dias por semana obrigatoriamente não estava em casa, e eram os três dias em que o Gabriel Garcia Marques, menino ainda, ia para a casa dessa mulher. E tem um momento interessante, em que ele está desabafando, dizendo que ele tinha um grande pesar na vida, porque ele odiava o curso de Direito - então ele levava livros de romances e punha embaixo da carteira e ficava lendo. E aí essa mulher deu a ele uma lição de Pedagogia, disse assim: olha, em toda aula, todo o professor diz o que importa nos primeiros

\footnotetext{
${ }^{6}$ Morais, Régis de (Org). Sala de Aula: que espaço é esse? Campinas: Editora Papirus, 1986.

${ }^{7}$ GARCÍA MÁRQUEZ, Gabriel. Viver para contar. Trad. Eric Nepomuceno. Rio de Janeiro: Record, 2003.
} 


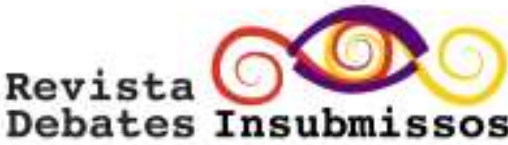

15 minutos, no resto ele enche linguiça. E ele adotou e virou bom aluno. O resultado é que eu estava dando um minicurso em um mestrado em Didática, em uma faculdade de educação em Pasto, e tive a ousadia de levar o livro do Garcia Márquez e apresentar como um dos três melhores livros de didática que eu já havia lido em minha vida...

A ousadia é uma das marcas de Carlos Brandão, que se expressa no fato de não acorrentar a educação em blocos de razão instrumental. Segundo suas palavras, a educação comporta "uma missão de partilha na criação de pessoas humanas críticas, criativas e participativas na construção de seus mundos" e que hoje "mais do que nunca, humanizar - criar, conviver e partilhar a construção solidária de um mundo justo e feliz - é educar”. Entre suas insubmissões afirma que "Formar pessoas livres através da educação é um momento essencial de todo o acontecimento da humanização”. E suas convicções foram construídas na certeza de que $\mathrm{o}$ ato de educar-se ocorre em todas as instâncias da vida cotidiana.

Nessa perspectiva, o diálogo apontou alguns dos espaços em que a educação se dá - e especificamente a Educação Popular - bem mais que naqueles construídos sob essa égide, como a Universidade.

Brandão: [...] Até hoje eu costumo estabelecer uma diferença entre viver a rotina universitária, o curso que eu tenho que fazer, a rotina, os trabalhos, com viver a vida universitária. Inclusive, em uma palestra sobre Educação Popular, em que o pessoal fala que ela nunca teve lugar na universidade, eu rebato que ela nunca teve lugar na estrutura universitária, mas desde Paulo Freire, sempre esteve nas brechas.... Na vida universitária, ele mesmo, foi em um serviço de extensão cultural que ele vai criar, com a primeira equipe dele, as primeiras experiências... $\mathrm{E}$ nós vivemos isso aí, eu ia para a universidade de manhã e saía à noite, então quando acabava a chatice da rotina universitária, começava a vida universitária. Inclusive era impressionante, era a estudantada gremial, através dos diretórios, que promovia semanas culturais, semanas de arte e a gente vivia isso. Então eu tenho uma enorme saudade do meu tempo de estudante na PUC ${ }^{8}$

\footnotetext{
${ }^{8}$ Pontifícia Universidade Católica do Rio de Janeiro, onde Brandão cursou sua graduação em Psicologia.
} 
porque foram anos de uma intensidade de vida universitária incrível, inclusive grande parte dos meus experimentos, por exemplo, círculos de cultura. No meu curso de Psicologia eu me especializei em dinâmica de grupo, e onde eu vivi as experiências disso foram em encontros, reunião de $\mathrm{JUC}^{9}$. A gente lia os cursos obrigatórios no curso de Psicologia, mas meu aprofundamento em teoria marxista, em Emanuel, Padre Henrique, Paulo Freire, tudo isso era depois das aulas, aliás era onde a gente estudava muito mais, eu fui um regular aluno de curso de Psicologia e um ótimo militante. Era essa dicotomia muito interessante, por exemplo, na Pedagogia não se lia Paulo Freire, mas a gente lia. Me lembro que naquele tempo a 'Pedagogia do Oprimido’ chegava mimeografado, escondido, e a gente lia como se fossem fascículos, não só Pedagogia do Oprimido como outros livros, marxistas inclusive. E eu vivi essa dupla experiência.

Destacamos aqui que já apontava Paulo Freire, em seu "Pedagogia da Autonomia", que “o educador democrático não pode negar-se o dever de, na sua prática docente, reforçar a capacidade crítica do educando, sua curiosidade, sua insubmissão" (FREIRE, 1996, p. 13, grifos nossos). Ou seja, a insubmissão é certamente, signo de resistência.

\section{O QUE A EDUCAÇÃO POPULAR TEM DE PRÁXIS INSUBMISSA?}

Recentemente eu estive [Valéria] em um "conversatório" muito bonito, estava o Oscar Jara, o Bauduíno Andreola, o Eymard Vasconcelos, entre tantas pessoas. Uma das professoras falou: é porque agora tem um monte de gente falando de Educação Popular, e fazendo essa crítica de que Educação Popular está virando uma "moda". E quando você traz essas insubmissões eu fico pensando no que há de genuíno na Educação Popular. O Oscar Jara contou histórias belíssimas e falou de resistência, da solidariedade voltar com uma força tremenda, que só assim que conseguiremos resistir. E ele falou na amorosidade e na solidariedade como uma insubmissão. Eu traduzo as suas palavras também nisso, porque a insubmissão é lidar com o

\footnotetext{
${ }^{9}$ Juventude Universitária Católica.
} 
outro com respeito e resistir a uma educação que não nos diz respeito. Aí a gente vai ler um livro, ou ficar na "turma de trás".

Sobre esse tema resgatamos algumas palavras de Brandão, em um dos tantos manuscritos não publicados, que ele partilha generosamente:

\begin{abstract}
Se nós, as pessoas que se reconhecem praticantes, militantes e participantes de algo a que ao longo desses anos todos nos têm reunido ao redor da Educação Popular, nos colocamos frente ao mundo em que praticamos esta modalidade humanista, crítica, criativa e transformadora da/através da educação, o que temos diante de nós é uma realidade que ao mesmo tempo em que dá continuidade aos anos em que "tudo começou", nos revela uma face múltipla, ou faces plurais em boa parte diversas e, em alguns casos, quase divergentes. Não esqueçamos que nos "tempos originais", tanto para a Cultura Popular quanto para a Educação Popular, o que nos movia eram palavras que continham ideias e acentuavam propostas regidas por: participação, transformação, revolução. Transformação de estruturas da mente, da consciência, da cultura, da sociedade, do mundo. Transformações radicais (desde as raízes), estruturais (não de partes ou sistemas da sociedade, mas dela toda) e socialmente populares (centradas em lutas e políticas "de classe"). Ou seja, transformações de toda uma sociedade e não adaptações ao estilo "desenvolvimentista" do sistema capitalista hegemônico (BRANDÃO, s.d., manuscrito não publicado)
\end{abstract}

A Educação Popular, ao longo de sua história da América Latina, se caracteriza pelas lutas para superar as mais diversas formas de injustiça, fortalecendo a criticidade de homens e mulheres que tomam a realidade opressora como substrato para sua insurgência. A EP é contra hegemônica, é dialógica, é democrática, é insubmissa.

\title{
3. SABERES TRADICIONAIS, O CAMPO E O RURAL, A EDUCAÇÃO POPULAR
}

Para Brandão e Borges (2014, p. 19) sujeitos povoadores e pertencentes às chamadas comunidades tradicionais

herdaram como uma comunidade, ou criaram e transformaram ao longo dos anos e através de gerações, sistemas apropriados ou próprios de saberes - as diferentes ciências populares - de representação da realidade e de atribuição de valores de conduta e de atribuição de identidade. Enfim, de tudo aquilo que no passar dos anos sustentou como sistemas de saber de práticas do fazer e de éticas do agir, a reprodução física e social da comunidade

As comunidades tradicionais rurais relacionam-se organicamente com a paisagem onde se inserem. Seus saberes constituem-se em práticas materiais e imateriais, conhecimentos "baseados-no-lugar" que são acúmulo de experiências e vivências cotidianas, fruto de práticas 


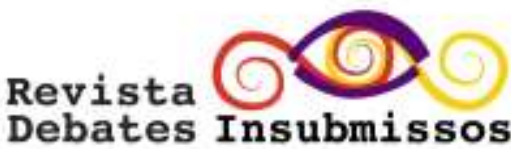

sociais e produtivas que moldam a cultura local e são moldados por ela, e cujos resultados são expressos na paisagem (STRACHULSKI; FLORIANI, 2016).

Brandão tem uma trajetória profundamente atrelada aos modos de viver e à cultura de populações rurais, pesquisando e orientando sobre distintas manifestações religiosas populares, sobre populações tradicionais, quilombolas, sertanejas, ribeirinhas, caiçaras, indígenas, entre outras. Nesses percursos de Educação Popular, Pesquisa Participante e Educação Ambiental, forjados na vida, foi tecendo uma estreita relação com o campo e com os espaços neo rurais.

Renata: Você acha que essa sua trajetória e esse seu desejo de estar sempre em contato com a natureza ajudou a formar esse seu perfil neo rural?

Brandão: Eu acredito que sim, inclusive eu escrevi sobre isso. Eu tive essa felicidade primeiro de ter nascido em Copacabana, mas em uma rua que terminava em um morrinho e que ficava a três minutos a pé da praia, então eu quase que aprendi a nadar e andar ao mesmo tempo. E depois eu fui morar na Gávea em uma rua que era encravada na pedra da gávea, então eu morava no Rio de Janeiro e na floresta, a minha rua ficava inteiramente dentro da mata, então eu convivi desde menino. Eu tenho um escrito que chama "Entre sanhaços, saguis e sabiás: uma biografia natural". É interessante que nem os ambientalistas tiveram essas ideias, eu começo dizendo o seguinte: que todo mundo escreve um curriculum vitae e uma biografia cultural com aquilo que leu, o que fez, o que estudou, e eu vou escrever uma "biografia natural". Eu que fui criado com bicho, sagui, mico, passarinho, depois casei com mulher e fui para Goiás. E assim foi minha vida, com onze anos ingressei em uma tropa de escoteiro, aliás tudo que eu ouço de ambientalista dizendo agora, a gente conversava com onze anos na tropa de escoteiro. Depois fui excursionista e depois fui escalador, quando eu fiz curso de guia excursionista e depois de escalador em 1959 e 60, a gente aprendia não só sobrevivência na floresta, mas uma coisa que chama legislação florestal, os cuidados com a natureza. Eu acho engraçado que eu nunca vi alguém da área de meio ambiente escrevendo biografia natural, só se escreve curriculum vitae, ninguém conta como cagava no mato.

Renata: Você acha que aí que entrou o rural na sua vida? 


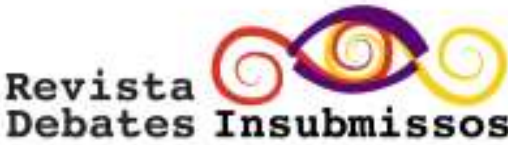

Brandão: Não, o rural entrou depois. Primeiro na minha vida por volta dos quatorze anos, o que entrou foi o campo, eu separo o campo do rural, o campo era onde eu como escoteiro e depois excursionista ia, no geral, todo o final de semana. Ou para matos aqui de perto ou então Teresópolis, Petrópolis, Itatiaia, nas escaladas, longas caminhadas, acampamento, para mim o paraíso até hoje é um acampamento. Então eu ia para o campo, mas não para o rural, eu não tinha nenhum contato com camponeses, a gente passava por eles sem ver, por isso eu entendo muita gente que faz isso até hoje. Em 1954, um tio meu, irmão mais moço da minha mãe, formado nas primeiras turmas de Viçosa como agrônomo, foi morar em Pouso Alegre (e morreu lá). E eu comecei a ir com a minha avó de trem. Naquele tempo o trem subia a Mantiqueira. Você ia do Rio à Cruzeiro e de Cruzeiro à Pouso Alegre de trem. Levava um dia inteiro, aí eu comecei a conhecer o rural, porque com esse meu tio agrônomo, que conhecia na palma da mão toda aquela região do sul de Minas. Ele me levava com ele, e foi a primeira vez que comecei a ver camponês, criação de porco, plantação de milho e atentar à essa gente. E foi um encantamento que perdurou ao longo da vida.

Importante enfatizar que o olhar para o campo e para o rural, mesmo na experiência desse antropólogo com visão diferenciada, não se deu "naturalmente". Faz-se necessária uma educação dos sentidos, que ocorre no cotidiano, na história, na vida.

$\mathrm{Na}$ continuação Brandão discorre sobre sua guinada entre escalador e pesquisador do campo e do rural.

Brandão: [...] na faculdade eu continuei escalando e levei amigos meus para escalaram comigo, e depois surgiram outras obrigações, outras vocações de militância, eu me filie à JUC [Juventude Universitária Católica] e de repente parei, aí eu vi que não dava. Interessante que recentemente saiu em português um livro de autor Istvan Mészáros chamado "A montanha que devemos conquistar: reflexões sobre o Estado" e ainda pensei que foi o que aconteceu na minha vida: eu passei de uma montanha para outra montanha, da montanha da natureza para a montanha da política. Até hoje para mim o símbolo de maravilha do mundo é uma montanha. [O rural] vai aparecer um pouco mais frente, eu diria até que a JUC, a Ação Católica, o MEB vão ser um pouco a pré-origem disso tudo, e os sindicatos rurais de camponeses cristãos dos 
quais eu lidei com muita intensidade. [...] E o que aconteceu? Eu ingressei na universidade em março e logo já estava em uma equipe de JUC, exatamente no momento em que a ação católica deu uma virada para o social, virada para o político. Para vocês terem uma ideia em 1962 a JUC fez uma frente única com o Partido Comunista Brasileiro, nós tínhamos uma frente única de trabalho. Militávamos cantando, educávamos poetando...

Renata: Você está falando e eu estou aqui viajando nessa sua trajetória o quanto a Educação Popular, o campesinato e a agroecologia estão aí presentes o tempo todo.

Brandão: Nos tempos de militância, de ação católica, de MEB e de movimentos estudantis, nós estudantes universitários tínhamos três questões fundamentais: uma era chamada questão universitária, era a luta pela reforma universitária e no bojo disso junto com o pessoal da JEC (Juventude Escolar Católica), a questão estudantil e a questão agrária que era a nossa luta ligada aos camponeses. E quando se começou a falar de questão ambiental, eu por exemplo, fui um dos primeiros inimigos: questão ambiental era papo de livro traduzido do inglês, era conversa de americano via CIA para fazer com que a gente deixa-se ou desqualifica-se a luta que importava, que era a reforma agraria, e começa-se a colocar outras lutas que eram absolutamente secundarias. Quantas vezes eu disse isso: que a questão do índio, questão feminista, questão do negro, questão ambiental, são questões secundarias, são questões do mundo do capitalismo. O que importa agora é a revolução socialista e, resolvido o dilema do capitalismo, no socialismo, não haveriam esses problemas. Interessante que até as mulheres concordavam, era uma espécie de "americanismo" você estudar naquela época o feminismo. É interessante observar que justamente nesse intervalo entre os anos 60 e os anos 80, o que acontece? Novos dilemas aparecem, a ditadura acaba, a revolução não se fez e de repente a questão da Amazônia, a questão do cerrado, a questão ambiental já começam a aparecer.

Alguns autores, como Torres Carrillo (2018), confirmam esse pensamento que Brandão confessa: na década de 1960, nos primórdios da Educação Popular, o foco central era o pensamento revolucionário em contraposição ao imperialismo estadunidense. 


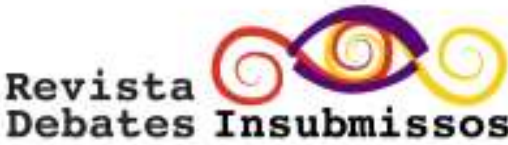

Brandão: Eu já estava na UNICAMP quando na primeira vez eu vou ler livros sobre questão ambiental. Inclusive, depois eu escrevi uns quatro livros (inclusive para crianças) sobre questão ambiental. A questão da mulher, eu já estava na UNICAMP quando ouvi falar sobre questão feminista, a questão indígena que já é um pouco antecedente, que vem inclusive através de antropólogos e a questão do negro, e só mais tarde a questão quilombola. E é interessante porque quando você pega Paulo Freire tem muito pouco disso nele, tem só de passagem, de raspão, porque ele já está velhinho nisso aí. Mas quando você pega outra geração, já é algo muito forte e candente, é o que a gente vai chamar, que vem da América espanhola para o Brasil, da reconceitualização da Educação Popular, que é uma coisa dos anos 1980, que é quando ela se abre.

Valéria: Você lembra de algum marco?

Brandão: Eu me lembro de uma grande conferência de educação de adultos com Paulo Freire, eu fui com ele para Buenos Aires e que pela primeira vez gente do Caribe vai falar da questão do negro, vai associar campesinato com a questão ambiental. Se você pegar a bibliografia dos primeiros livros que eu escrevi você vai ver: "Pensar a prática", "Lutar com a palavra”, e depois livros centrados em Educação Popular mais abertos, e depois educação para paz, Educação Ambiental. [...] Pouca gente sabe, mas o MST é um dos movimentos mais agroecológicos do Brasil. Hoje, a partir do momento que o pessoal do MST começou a conquistar e consolidar territórios nas ocupações e começou a produzir, descobriu que ou produzia agroecologicamente ou não tinha futuro. [...] o MST hoje em dia virou um exemplo de produção ecológica, fora as lutas hoje em dia na Amazônia. Me lembrei de uma frase de Margarida Maria Alves que ela disse uma das coisas mais sábias e bonitas e que a gente tem que ter como lema nos dias de hoje. Alguém perguntou a ela "Dona Margarida, com tantos perigos e ameaças vocês não têm medo não?” E ela respondeu: “olha, medo nós tem, mas não usa”!! Isso é um lema para vocês!

Renata: Brandão, quando você estava contando essa transição da Educação Popular, quando ela começa a dialogar com essas outras pautas você falou a palavra "dilemas", que começaram a aparecer novos "dilemas". 
Brandão: A questão feminista, a questão ambiental, educação em direitos humanos, a questão do negro, a questão das minorias eróticas, tudo isso que a gente colocava em baixo do saco da "revolução socialista" que só tinha operariado e campesinato e que, de repente, aparecem como dilemas e como dilemas dignos de serem anotados, inclusive autores marxistas começam a atentar com essas questões e aí é incorporado. Hoje em dia a gente fala de Educação Ambiental Popular.

Valéria: Brandão, nos ajude a pensar nessa questão da virtualidade, porque você que tem mais de 60 lives nesses últimos tempos de pandemia.

Brandão: Olha, essa questão do que está acontecendo, não do ponto de vista politico porque aí é outra conversa, mas do ponto de vista cultural e afetivo, eu vejo com olhos de grande horizonte, não de pequeno horizonte. $\mathrm{Eu}$ acho que as pessoas estão apequenando muito o horizonte. Inclusive, quando vejo pessoas dizendo que o mundo vai acabar por conta do Bolsonaro eu digo que nasci no primeiro ano da guerra (II Guerra Mundial). Quando ela acabou eu tinha cinco anos, eu atravessei vinte e dois anos da ditadura militar, depois acompanhei a ditadura da Argentina, do Chile, do Equador.... Porque principalmente naquele tempo a gente tinha uma ligação muito intensa, principalmente por conta da Educação Popular, e tudo isso passou, e nós estamos aí. E essas coisas eletrônicas, eu vejo com muita naturalidade e estranhamento, você sabe quando a imprensa foi inventada pelo Gutemberg durante muito tempo ela foi combatida pela igreja católica, inclusive por intelectuais que associavam a imprensa como o fim da "civilização". Porque no momento que você tem milhares de livros distribuídos [colocaria em risco esse grupo] - porque eles consideravam "civilização" a pequeníssima parcela de pessoas que tinham livros e sabiam ler e escrever - e o mundo continuou. Então eu tenho a impressão que nas suas tropelias, a experiência e a sabedoria da humanidade é muito maior do que a gente imagina.

Valéria: Você vê, então, possibilidades de insubmissão mesmo dentro de um ambiente tão moderno e capitalista? 


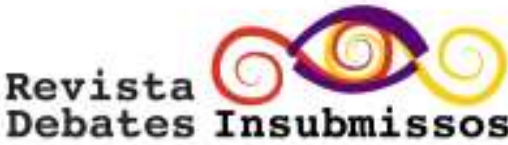

Brandão: Por exemplo, essas "lives, para mim é a coisa mais contraditória, porque do ponto de vista pessoal eu acho horrível. Eu queria agora estar frente a frente com vocês, queria que terminasse com a gente bebendo vinho e se abraçando. Eu que tenho vivido "lives" desde quatro pessoas até quatro mil, é uma coisa muito contraditória, primeiramente é a impressão que pouca gente se toca, porque quando você vive presencialmente você é invisível para você mesmo, você está dando uma aula, ou você está frente a uma plateia, e você vê todo mundo menos você, então você está diante do Outro. E uma coisa muito curiosa, agora nesse momento eu estou falando para vocês sem me ver, então eu não sei como estou, mas sei como vocês estão.

Valéria: Quais alternativas você vislumbra?

Brandão: E agora é muito interessante porque a "live" cria alternativas: agora estamos conversando a três, ontem tinha cento e poucas pessoas, outro dia tinham quatrocentas e poucas, e além disso elas são gravadas, então qualquer um pode acessar. Então tem esse dado de multiplicação, porque durante anos isso fica aberto, então tem grandes vantagens e desvantagens. Eu acho que a sabedoria do mundo vai ser lidar com o equilíbrio. [...] Desde a nossa vida sexual e erótica até no mundo científico, hoje em dia é incrível que você produz um artigo e, de repente, no dia seguinte ele pode estar diante de quatro mil pessoas, dependendo dessas redes. Então são coisas que vem para o bem e para o mal, assim como tudo na vida.

Valéria: O que é necessário ter em mente quando se fala em educação a distância?

Brandão: Eu não quero fazer uma análise política, porque isso é outro papo, para outras pessoas, mas sob o ponto de vista cultural, eu vejo como uma grande contradição. As pessoas quando falam em "ensino a distância", a maioria pensa apenas no aspecto cultural, mas eu sempre gosto de me remeter a uma revista que é da “ADUSP”, da Associação dos Docentes da USP, e é interessante que é um número dedicado ao produtivismo na universidade. E o interessante é que é um número internacional, tem artigos de uma pessoa no Japão, na Austrália, na Holanda e no Brasil. E é interessante que todos, de uma maneira uniforme, estão tocando na mesma tecla. A questão não é puramente tecnológica, se é a distância, se é interétnica ou não, a questão é quem está politicamente se apropriando disso aí. Então eles trabalham com a 
contraface disso aí, de repente todo esse apanágio eletrônico ele tem a sua contraface, que é o controle do mundo do capital e que impõe agora produção quantitativa. Então todos eles, do Japão ao Brasil estão tocando na mesma tecla, mercantilização, pragmatismo, o apressamento das relações, o produtivíssimo. Até sobre contabilidade, eu estava nessa live com o pessoal do Centro Paulo Freire contando uma historinha, uma das minhas aulas me ensinou a entrar no Google Escola, uma vez eu entrei e constatei que eu tinha treze mil e tantos acessos, de pessoas que acessaram coisas minha e eu fiquei em uma vaidade, aí me veio a curiosidade e eu cliquei em Paulo Freire, tinham quatrocentos e sessenta e poucos mil.

\title{
4. COMO O ENSINAR-E-APRENDER NO ESPAÇO ESCOLAR PODE DIALOGAR COM A EP E COM OS SABERES TRADICIONAIS?
}

Para Brandão "humanizar é educar”. Ele afirma que:

\begin{abstract}
A educação deve ser pensada como uma vivência solidária de criação de sentidos ao longo de toda a vida e em cada um dos momentos da vida de cada ser humano. E não apenas porque ela é a "educação de um mundo em contínua mudança". Mas porque a educação deve se constituir como um lugar essencial e não substituível na busca e criação de sentidos pessoais e partilhados de vida, que participem de maneira crítica e consciente da orientação das próprias transformações do Mundo e da Vida (BRANDÃO, s.d., manuscrito não publicado).
\end{abstract}

Sua rebeldia na educação se mostrou desde suas primeiras experiências como professor:

Brandão: Aí começa a insubmissão, eu lembro da minha primeira aula, 15 de agosto de 1967. E em agosto, as vezes lá no cerrado é o mês mais quente, quente e seco. E nós lá na sala de aula e do lado uma arvore com uma sombra e eu cheguei: gente, está muito quente aqui, vamos sentar ali em baixo daquela árvore? Minha primeira aula foi em um círculo que aliás, adotamos. Era aula de filosofia da educação, nunca tinha dado, mas a carência de professores era tal.

E é importante ressaltar que não é somente esse formato circular que vai caracterizar a insubmissão: é a busca pela sombra de uma mangueira (como fazia Freire), a proximidade com a natureza, a dialogicidade e horizontalidade nas relações, o processo de aprender-e-ensinar em círculos de cultura, a construção de conhecimentos partilhados, na escola e fora dela: 


\section{wartate \\ Debates Insubmissos}

[...] a razão de ser do ser humano em sua individualidade e em sua vocação à busca de comunhão consigo mesmo e com os outros é a inacabável construção de si-mesmo no abrir-se ao outro, e no construir com ele o cotidiano livre e solidário de seu próprio mundo. Esta "construção" nasce do exercício contínuo de aprendizagens partilhadas (e, se possível, não "a distância"), dentro de um crescendo da sensibilidade, da amorosidade, da criação pessoal e interativa de saberes e da invenção inacabável e igualmente interativa de sentidos e de significados de vida e de destino [...] O aprender a que serve a educação é uma razão de ser essencial da própria experiência humana. E é, mais do que tudo, aquilo que nos torna humanos a cada instante e aquilo que possibilita, em cada uma e em cada um de nós, um ir-além-de-si-mesmo infindo. Não somos o que somos, mas somos o que aprendemos a ser a cada instante da vida. A educação como um lugar-eixo de todo o campo das interações humanas em qualquer lugar e a qualquer momento. "Que tipo de pessoa pretendemos formar através da educação que praticamos?” (BRANDÃO, s.d., manuscrito não publicado).

\section{DERRADEIRAS PALAVRAS}

Esse diálogo nos proporcionou uma ótima oportunidade de (re)encontro, mesmo que mediado pelas tecnologias da informação. Temos, já há muitos anos, tido o privilégio de conviver com Carlos Rodrigues Brandão, trabalhando em algumas iniciativas e projetos, principalmente na Rosa dos Ventos - sítio de sua propriedade que é um modelo de proposta neo rural, cuja principal prerrogativa é a partilha e a acolhida de pessoas, culturas e saberes tradicionais. Pisar nesse chão é caminhar sobre o solo da Educação Popular e da Economia Solidária e esse é o retrato que melhor ilustra a coerência desse antropólogo entre seus dizeres e fazeres.

Entre algumas das principais qualidades desse pesquisador e poeta estão a generosidade, a insubmissão e sua profunda esperança num “outro mundo possível”. E isso também passa pela ética, pela estética e pelo riso, como ilustra esse último recorte:

Brandão: E eu achei bonito, esse artista que morreu, Paulo Gustavo, deu uma mensagem quando ele ainda estava bem, e eu achei muito bonito e fiquei tocado, por ser de um homem que viveu da comédia...ele termina dizendo "não esqueçam que o riso é uma arma de resistência". 


\section{REFERÊNCIAS}

BRANDÃO, C.R. A comunidade tradicional. In: Udry, C.; Eidt, J. S. (Eds). Conhecimento Tradicional: Conceitos e Marco Legal. Brasília, EMBRAPA, p. 21-102, 2015.

BRANDÃO, C. R. (s.d.) Sete lembranças e divagações a respeito da Educação Popular. Disponível em: https://apartilhadavida.com.br/ Acesso em: 30 de maio de 2021.

BRANDÃO, C. R.; BORGES, M. C. O lugar da vida: Comunidade e Comunidade Tradicional. Campo-território: Revista de geografia agrária, Ed. Especial, p. 1-23, 2014.

SANTOS, Boaventura de Sousa. A gramática do tempo: para uma nova cultura política. Porto: Edições Afrontamento, 2006.

STRACHULSKI, J.; FLORIANI, N. Saber ecológico tradicional da Comunidade Rural Linha Criciumal, Cândido de Abreu - PR: Práticas e representações da fertilidade das terras. Revista da Anpege, v. 12, n. 7, p.219-256, 2016.

TORRES CARRILlO, Alfonso Torres. La Educación Popular. Trayectoria y actualidad. Bogotá: El Buho Editorial, 2008.

Submetido: $28 / 06 / 2021$

Aprovado: $27 / 07 / 2021$ 